\title{
Tímabundið átak eða framtíðarlausn?
}

Mikið álag á bráðamóttöku Landspítala var endurtekið fréttaefni í fjölmiðlum landsins í ársbyrjun. Vandamálið hafði lengi verið til umræðu og hafði Embætti landlæknis meðal annars gert alvarlegar athugasemdir í kjölfar úttektar. Staðan var sú að fjöldi sjúklinga lá að jafnaði á göngum bráðadeildarinnar bíðandi eftir plássi á legudeildum spítalans, sem er talið sjúklingum hættulegt. Már Kristjánsson yfirlæknir smitsjúkdómalækninga lýsti pessari óboðlegu stöðu vel í viðtali í Læknablaðinu í janúar („Stórslys í aðsigi á bráðamóttökunni“).

Í kjölfarið hélt Félag sjúkrahúslækna fjölmennan fund par sem sampykkt var harðorð ályktun um málið. Læknaráð Landspítala sendi frá sér prjár ályktanir um vanda bráðamóttökunnar á aðeins rúmu ári, fyrst 10. desember 2018, næst 14. júní 2019 og loks 8. janúar 2020. Prátt fyrir síendurtekin varnaðarorð lækna virtist lítið um viðbrögð.

Раð hitnaði svo rækilega í kolunum á almennum Læknaráðsfundi á Landspítala með Svandísi Svavarsdóttur heilbrigðisráðherra pann 13. janúar pegar Ragnar Freyr Ingvarsson læknir greindi frá „neyðarástandi og skelfingarflækju“ á bráðamóttökunni. Premur dögum síðar, pann 16. janúar, var tekin ákvörðun um skipun sérstaks átakshóps á sameiginlegum fundi heilbrigðisráðherra, landlæknis og forstjóra Landspítala.

Eflaust hafa einhverjir hrist höfuðið pegar fréttir bárust af stofnun „átakshóps“ enda hefur vandi Landspítala og bráðamóttökunnar farið vaxandi undanfarin ár og snertir í raun allt heilbrigðis- og velferðarkerfið. Skýrsla hópsins var kynnt 25. febrúar síðastliðinn og par voru lagðar fram 11 tillögur sem raðаð var í forgangsröð og með tímamörkum. Fyrsta tillagan er að „Forstjóri og framkvæmdastjórn Landspítala taki pegar í stað stefnumarkandi ákvörðun um að sjúklingar á bráðamóttöku spítalans sem purfa innlögn flytjist á viðeigandi legudeildir sem fyrst". Samdægurs var sampykkt formlega á fundi framkvæmdastjórnar spítalans að fara að tillögunni og tekin ákvörðun um að sjúklingar skuli ekki bíða innlagnar lengur en 6 klukkustundir. Mat tveggja erlendra sérfræðinga fylgdi skýrslunni par sem fram kom að ekki hefði verið ráðist að rót vandans og að Landspítali pyrfti að taka að sér forystuhlutverk við úrlausn hans.

Ekki gefst rými í pessum leiðara til að greina nánar frá efni skýrslunnar og öðrum tillögum hópsins en pegar petta er ritað hafa orðið jákvæðar breytingar á bráđamóttökunni. Sjúklingum sem bíða innlagnar hefur snarfækkað og aðstæður á bráðadeildinni hafa batnað. Раð er ljóst að hluti af lausninni var sú heppilega staðreynd að hægt var að nýta pláss á nýju hjúkrunarheimili en ráðherra tók ákvörðun um að sjúklingar á Landspítala fengju forgang að peim. Рað er líka ljóst að ný hjúkrunarheimili opna ekki á hverjum degi. Pví vaknar sú spurning hvort pessi árangur verði aðeins tímabundinn eða hvort um langtímaárangur sé að ræða. Раð verður grannt fylgst með próun mála á bráđamóttökunni og raunar Landspítala öllum en tíminn mun leiða í ljós hvort pessi góði árangur helst eða hvort aftur sígi á ógæfuhliðina.

Ekki er hægt að stinga niður penna pessa dagana án pess að minnast á COVID-19-faraldurinn sem geisað hefur um landið og heimsbyggðina alla undanfarnar vikur. Teymið sem stýrir viðbrögðum við faraldrinum hefur hlotið mikið lof fyrir framgöngu sína. Einnig hafa stjórnvöld sýnt skynsemi með pví að hlusta á ráðleggingar fagfólks og láta fagleg og læknisfræðileg rök vega pungt við ákvarðanatöku. Pað sýnir sig nú sem oft áður að pegar alvarlega og bráða ógn ber að garði stendur íslenskur almenningur saman og allir leggjast á árarnar. Pannig er hægt að áorka miklu, eins og að prófa metfjölda einstaklinga fyrir sýkingu og opna nýja göngudeild COVID-19-sjúklinga.

Раð er óskandi að samtakamáttur almennings, stofnana, heilsugæslu, sjúkrahúsa og stjórnvalda haldi áfram pegar faraldurinn er genginn yfir. Vonandi verður sá lærdómur dreginn að gæfuríkast

Viőbrögõ viô COVID-19 sýna að̃ lyfta má grettistaki í heilbrigðismálum pegar ógn steðjar að̃ og pví verður ekki lengur unaô viố endurtekiô krísuástand og „fráflæðivanda“ á Landspítala. Vandinn er mannanna verk og verkefni stjórnvalda að leysa hann. ábendingar lækna og annars heilbrigðisstarfsfólks pegar kemur að heilbrigðismálum. Einnig færir farsóttin okkur heim sanninn um mikilvægi pess að setja nægilegt fjármagn í rekstur heilbrigðiskerfisins, kerfisins sem grípur okkur og ástvini okkar pegar veikindi koma upp.

Nú pegar við verðum vitni að pví grettistaki sem lyfta má í heilbrigðismálum pegar ógn á borð við COVID-19 steðjar að er ljóst að ekki verður lengur unað við endurteknar „hversdagskrísur“ á borð við yfirfulla bráðamóttöku og "fráflæðivanda“ Landspítala. Vandinn er ekki náttúrulögmál heldur mannanna verk og pað er óumdeilanlega verkefni íslenskra stjórnvalda og heilbrigðisstofnana að leysa hann.

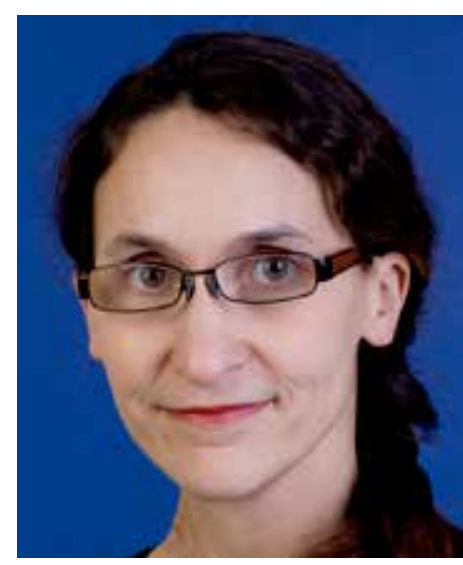

\section{Anna Margrét Halldórsdóttir}

sérfræðilæknir

Blóðbankanum Landspítala

starfandi formaður Læknaráđs Landspítala klínískur dósent, læknadeild Hí

annamha@landspitali.is

A temporary measure or permanent solution?

Anna Margrét Halldórsdóttir MD, PhD, Specialist in Clinical Pathology/ Transfusion Medicine. Consulting Physician, Department of Transfusion Medicine, Landspitalinn. Clinical Associate Professor, University of Iceland. Acting chair, Landspitali Medical Board.

DOI:10.17992/Ibl.2020.04.573 